Plant Tissue Cult. \& Biotech. 28(1): 99-108, 2018 (June)

$\overline{\text { PTC\&B }}$

\title{
Endogenous Bacterial Contamination of Plant Tissue Culture Materials: Identification and Control Strategy
}

\author{
Mohammad Ali ${ }^{*}$, Shefali Boonerjee ${ }^{2}$, Mohammad Nurul Islam, \\ Mihir Lal Saha, M. Imdadul Hoque and Rakha Hari Sarker
}

Department of Botany, University of Dhaka, Dhaka-1000, Bangladesh

Key words: Bacterial contamination, Plant tissue culture, Control

\begin{abstract}
The endogenous bacterial contamination of plant tissue culture materials and their possible control was studied. Nine bacterial isolates were isolated from the contaminated tissue culture materials viz. potato and tea. On the basis of morphology and biochemical characters of nine isolates, seven were identified as Gram positive belonging to Bacillus alcalophilus, B. circulans, B. infantis, B. lentus, B. schlegelii, B. pumilus and B. subtilis. Remaining two were Gram negative and identified as Enterobacter cloacae sub. sp. dissolvens and Pantoea agglomerans. Molecular analysis was conducted on the basis of $16 \mathrm{~S}$ rDNA sequence to confirm three isolates. Culture and sensitivity test was carried out to screen out the antibiotic sensitivity where streptomycin (S-10), polymyxin (PB-300) and gentamicin (CN-120) antibiotics were found to be effective against all bacterial isolates. The culture and sensitivity test reflected the feasibility to control or eliminate the contaminant bacteria during in vitro culture of plant which is very much required in the commercial tissue culture production.
\end{abstract}

\section{Introduction}

Micropropagation is a tool which rapidly multiplies the genetically identical plants by using modern techniques and relatively small space, supplies and time. A small piece of explants such as a meristem, stem tip, node etc. is placed in a sterile nutrient medium (usually gel-based) where the inoculated plant parts are multiplied (Daniel 1998). Presently, the micropropagation is practiced comprehensively for the development of plants with pest or stress resistance and pathogen free plants production (Kolomiets et al. 2014, Sharma and Agrawal 2012). Although, the plant materials used in tissue culture are disinfected using

*Author for correspondence: <mdalibotdu@yahoo.com>. ${ }^{1}$ Present address: Department of Botany, Jagannath University, Dhaka-1100, Bangladesh. ${ }^{2}$ Statistics \& Economics Division, Bangladesh Tea Research Institute (BTRI), Srimangal-3210, Moulvibazar, Bangladesh. 
surfectants to remove microbes and all vessels and media were sterilized properly (George 1993), there are some reports in which microbial contamination in tissue culture is said to restrict the improvement of all in vitro techniques (Leifert and Cassells 2001).

Potato (Solanum tuberosum L.) has been considering as an important food crop throughout the world. Now, potatoes are cultivated in almost every part of the world, with annual global production exceeding 300 million tons (Camire et al. 2009) and thus it is considered the fourth largest food crop in the world. It is relatively sensitive to environmental stresses (i.e. salinity, drought etc.) where tuber initiation, tuber growth stages of potato had shown susceptibility to drought stress (Evers et al. 2010). The environmental stresses on potato crops were possible to overcome using plant tissue culture. However, some microbial contaminations are noticed in tissue culture of potato plant which need to be avoided for higher yield of potato.

Tea (Camellia sinensis (L.) Kuntze) is another popular plant and a major cash crop in most of the developing countries including Bangladesh. Bangladesh cater 3 per cent of global tea production, which plays an important role in building the national economy. Next to water, tea is the most consumed beverage and synthesis a lot of medicinally important secondary metabolites i.e. vitamins (C, E and $\mathrm{K})$, caffeine, polysaccharides, lutein and theanine which are needed for health (Mondal et al. 2004, Lee et al. 2014). The high genetical heterozygocity of existing Camellia varieties are hampering in steady production of metabolites which could be overcome by using in vitro culture. Secretion of phenolic exudants from the explants attracts microbes and shows susceptibility to pathogens which cause major damage in sapling of tea leading to drastic losses of cultures at each stage of micropropagation which eventually triggering economical losses every year (Mondal et al. 2004). Thus, special attention on microbial control should be given to increase the productivity of in vitro culture regardless of microbial contamination.

Nutrient medium is used for in vitro culture of plant which is also a good source for microbial growth. The microbes grown in tissue culture media may compete adversely with plant tissue culture for nutrient (Odutayo et al. 2007). As a result, endogenous bacterial contamination is said to pose a great problem for in vitro micropropagation of plants including potato and tea species instigating latent infection (tissue necrosis, diminished shoot proliferation etc.) in plant tissue culture (Kane 2003). Eventually, loss of a huge amount of money, man hours and effort spent in culture development and experiment set up are commonly occurring (Jang-Jih et al. 2000). Considering the said situation, the aim of the present study was the isolation, characterization of endogenous bacteria 
responsible for contamination of potato and tea shoots as well as to find out the suitable antibiotics that would be most effective for contamination free of tissue culture products.

\section{Materials and Methods}

In vitro grown explants, shoots/plantlets of potato and tea and their contaminated culture flasks were used as materials for this study. The contaminated materials were collected from the Plant Breeding and Biotechnology Laboratory, Department of Botany, University of Dhaka. The explants were cultured on MS basal medium supplemented with various growth hormones at $\mathrm{pH} 5.8$.
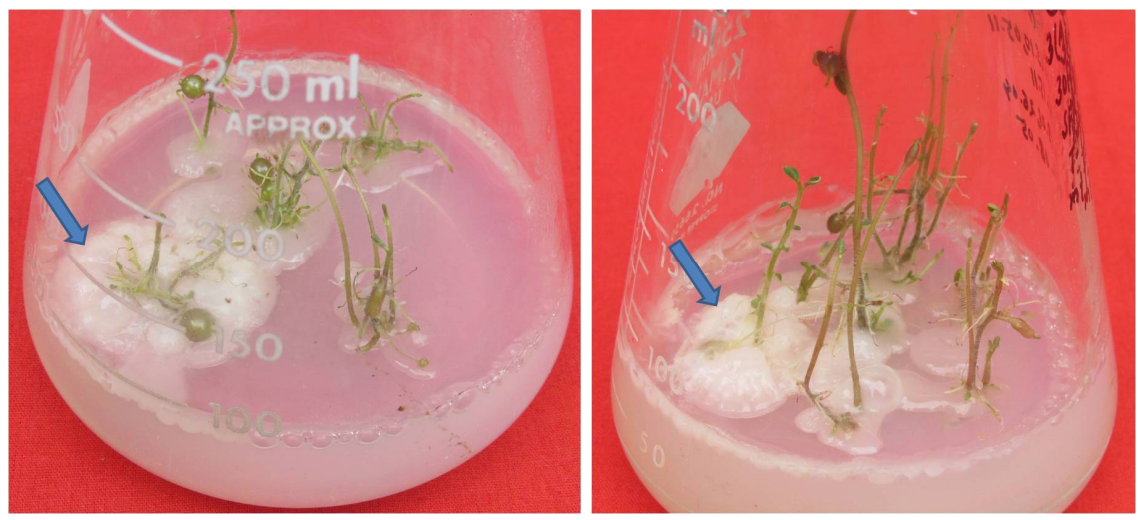

Fig. 1. Endogenous bacterial growth at the base of explants during in vitro potato culture.

Isolation and identification of the endogenously contaminant bacteria: The endogenous bacterial contaminants were found in the form of colonies at the base of in vitro culture of potato and tea (Fig. 1). The colonies were transferred to nutrient agar medium. The isolated contaminants were purified by serial dilution and repeated streaking technique (Collins and Lyne 1984). The purified bacterial isolates were preserved in a refrigerator at $4^{\circ} \mathrm{C}$ for further study.

Isolated bacteria were observed under microscope after simple, Gram and spore staining. Major biochemical tests including catalase production, oxidase test, indole production, citrate utilization, urease activity, hydrogen sulphide production, casein hydrolysis, starch hydrolysis and carbohydrate utilization were carried out for provisional identification of the selected isolates (Collins and Lyne 1984, Krieg and Holt 1984, Sneath et al. 1986). Bergey's manual of systematic bacteriology was followed for the identification of aerobic Gram positive bacteria (Sneath et al. 1986) and Gram negative bacteria (Krieg and Holt 1984, WHO 1987). 
Molecular analysis: Among nine isolates, three were selected for the sequencing of $16 \mathrm{~S}$ rDNA to identify specific bacterium. The molecular analyses of the selected isolates were conducted following the standard procedures as described by Marchesi et al. (1998). Bacterial cells were heat lysed in boiling water bath for $5 \mathrm{~min}$ and centrifuged for $1 \mathrm{~min}$ at 13,000 rpm. The supernatant was used as a source of DNA in the PCR. 16S rDNA gene was amplified using universal primers. The PCR was done with an initial denaturation at $95^{\circ} \mathrm{C}$ for 5 min. The denaturation at $94^{\circ} \mathrm{C}$ for $1 \mathrm{~min}$, annealing at $60^{\circ} \mathrm{C}$ for $30 \mathrm{sec}$ and extension at $72^{\circ} \mathrm{C}$ for $30 \mathrm{sec}$ were followed by 30 cycles of amplification reactions. The final extension was at $72^{\circ} \mathrm{C}$ for $5 \mathrm{~min}$. When the PCR was completed, the size of the DNA band was checked by agarose gel (1\% agar in $0.5 \mathrm{X}$ TBE solutions) electrophoresis.

DNA amplified by PCR was gel purified using Qiagen kit. The sequences generated by the automated sequencing of PCR amplified DNA was analyzed through BLAST program (http:/blast.ncbi.nlm.nih.gov/) to find out the correct match of the bacterial isolates. Sequence alignment and phylogeny reconstruction were performed on MEGA 6 using CLUSTAL $W$ and maximum likelihood packages, respectively. The consensus tree generated was tested by bootstrapping (1000 times).

Culture and sensitivity (C/S) test of the selected bacterial isolates: The Kirby-Bauer method was followed for the C $S$ test (Claus 1995). This test was carried out by inoculating selected isolates in Mueller-Hinton agar medium. The C $S$ test was performed on test bacterial isolates using seven different antibiotic discs, viz. neomycin (N-30), streptomycin (S-10), gentamicin (CN-120), vancomycin (VA30), penicillin (P-10), rifampicin (RD-5) and polymyxin (PB-300). The discs containing antibiotics were then aseptically placed on inoculated contaminant bacterial plates. The inoculated plates were incubated at $37^{\circ} \mathrm{C}$ for $24 \mathrm{hrs}$. The diameters of the developed inhibition zones around the discs were measured and recorded.

\section{Results and Discussion}

Nine bacterial strains were isolated from the contaminated tissue culture flask of potato and tea plants. Microscopic observation revealed that all of the bacterial isolates were rod and short rod shaped (Table 1). Moreover, vegetative cells, spores, sporangia and Gram reaction were critically examined. Gram staining exhibited seven isolates as Gram positive while remaining two were identified as Gram negative. Among seven Gram positive bacteria five were spore former and the remaining two were non-spore former. All of the bacterial isolates showed motile in motility test. 
Provisional identification of contaminant bacteria: On the basis of major biochemical tests provisional identification of the selected isolates was presented in Table 2. All the isolates were positive for catalase and L-arabinose test while propionate was found to be negative. Among nine isolates, six were obligate aerobic and the rest three were facultative anaerobic. All the Gram positive bacteria belonged to the genus Bacillus which included seven different species viz. B. alcalophilus, B. circulans, B. infantis, B.lentus, B. schlegelii, B. pumilus and

Table 1. Microscopic observation of the endogenous bacterial isolates.

\begin{tabular}{|c|c|c|c|c|c|c|}
\hline \multirow[b]{2}{*}{ Isolates } & \multicolumn{6}{|c|}{ Microscopic observation } \\
\hline & $\begin{array}{l}\text { Vegetative } \\
\text { cells }\end{array}$ & $\begin{array}{c}\text { Gram } \\
\text { reaction }\end{array}$ & Motility & Spores & Spore type & Sporangium \\
\hline Pot-1 & Rod & $+\mathrm{Ve}$ & Motile & Spore former & Ellipsoidal & Swollen \\
\hline Pot-2 & Rod & $"$ & $"$ & $"$ & Oval & $"$ \\
\hline Pot-3 & Short rod & $-\mathrm{Ve}$ & $"$ & Non-spore former & - & - \\
\hline $\mathrm{T}-1$ & Rod & $"$ & $"$ & $"$ & - & - \\
\hline $\mathrm{T}-2$ & Short rod & $+\mathrm{Ve}$ & $"$ & Spore former & Oval & Swollen \\
\hline $\mathrm{T}-3$ & Short rod & $"$ & $"$ & " & Spherical & $"$ \\
\hline $\mathrm{T}-4$ & Short rod & $"$ & $"$ & $"$ & Oval & $"$ \\
\hline $\mathrm{T}-5$ & Rod & $"$ & $"$ & Non-spore former & - & - \\
\hline T-6 & Short rod & $"$ & $"$ & $"$ & - & - \\
\hline
\end{tabular}

Pot $=$ Bacteria isolated from potato culture and $\mathrm{T}=$ Bacteria isolated from tea culture.

Table 2. Biochemical characteristics of the provisionally identified bacteria.

\begin{tabular}{|c|c|c|c|c|c|c|c|c|c|c|c|}
\hline \multirow{2}{*}{$\begin{array}{l}\text { Iso- } \\
\text { lates }\end{array}$} & \multicolumn{11}{|c|}{ Biochemical characteristics } \\
\hline & $\overline{\mathrm{VP}}$ & DGA & $\begin{array}{l}\text { Glu- } \\
\text { cose }\end{array}$ & $\begin{array}{l}\text { D-xy- } \\
\text { lose }\end{array}$ & Casein & Starch & Citrate & Indole & $\begin{array}{c}\mathrm{NO}_{3} \\
\text { reduction }\end{array}$ & $\begin{array}{c}\text { Tyrosine } \\
\text { degra- } \\
\text { dation }\end{array}$ & $\begin{array}{l}\text { Provisional } \\
\text { identification }\end{array}$ \\
\hline$\overline{\text { Pot-1 }}$ & - & $\mathrm{OA}$ & - & - & + & + & + & + & + & - & Bacillus infantis \\
\hline Pot-2 & - & $\mathrm{OA}$ & + & + & + & + & + & - & - & - & B. alcalophilus \\
\hline Pot-3 & - & FA & + & + & - & + & + & - & - & - & $\begin{array}{l}\text { Enterobacter cloacae } \\
\text { sub. sp. dissolvens }\end{array}$ \\
\hline $\mathrm{T}-1$ & + & $\mathrm{OA}$ & - & + & - & - & - & - & + & - & Pantoea agglomerans \\
\hline $\mathrm{T}-2$ & + & $\mathrm{OA}$ & - & + & - & - & - & + & + & - & Bacillus lentus \\
\hline $\mathrm{T}-3$ & + & FA & - & + & - & - & - & - & + & - & B. schlegelii \\
\hline $\mathrm{T}-4$ & - & FA & - & + & - & - & - & - & + & - & B. circulans \\
\hline $\mathrm{T}-5$ & + & $\mathrm{OA}$ & Alk & + & - & - & - & - & - & + & B. pumilus \\
\hline $\mathrm{T}-6$ & + & $\mathrm{OA}$ & Alk & + & - & - & - & + & + & + & B. subtilis \\
\hline
\end{tabular}

DGA = Deep glucose agar, $\mathrm{OA}=$ Obligate aerobic, $\mathrm{FA}=$ Facultative anaerobic .

B. subtilis. The Gram negative isolates were identified as Enterobacter cloacae sub. sp. dissolvens and Pantoea agglomerans. The identification results had shown that 
most of the contaminant bacteria belonged to Bacillus. Similar observations were made by Habiba et al. (2002).

Molecular identification: Molecular analysis was carried out to confirm the identification of few selected bacteria found as tissue culture contaminant. Among nine isolates, three were confirmed by the results of $16 \mathrm{~S}$ rDNA sequences analysis (Table 3). BLAST results of the rDNA sequences of the bacteria and their basic bioinformatic parameters are shown in Table 3. Based on BLAST results, one isolate was identified as the genus Bacillus infantis having 98\% similarity while other two were detected as Pantoea agglomerans and Enterobacter cloacae sub. sp. dissolvens, respectively.

Table 3. Basic bioinformatic parameters of the bacteria isolated from the tissue culture contaminants.

\begin{tabular}{|c|c|c|c|c|c|c|c|}
\hline \multirow{2}{*}{ Isolates } & \multicolumn{2}{|c|}{$\begin{array}{l}\text { Name and accession number of the } \\
\text { bacterial strain having highest similarity }\end{array}$} & \multicolumn{5}{|c|}{ Basis of the bioinformatics parameters } \\
\hline & $\begin{array}{l}\text { Accession } \\
\text { number }\end{array}$ & Strain name & Score & Bits & $\begin{array}{l}\text { Expect } \\
\text { value }\end{array}$ & $\begin{array}{l}\text { Identities } \\
(\%)\end{array}$ & $\begin{array}{c}\text { Gaps } \\
(\%)\end{array}$ \\
\hline Pot-1 & HQ234278.1 & Bacillus infantis & 989 & 535 & 0.0 & 98 & 2 \\
\hline Pot-3 & HQ434623.1 & $\begin{array}{l}\text { Enterobacter cloacae sub. sp. } \\
\text { dissolvens }\end{array}$ & 926 & 501 & 0.0 & 96 & 1 \\
\hline $\mathrm{T}-1$ & JN036646.1 & Pantoea agglomerans & 981 & 531 & 0.0 & 98 & 2 \\
\hline
\end{tabular}

Phylogenetic tree constructed based on the DNA sequences of the isolates are shown in Fig. 2. The phylogenetic tree was generated using MEGA 6.0 (Tamura et al. 2013) software with the Neighbor Joining (NJ) algorithm based on 16S rDNA sequence. Bootstrap values for 1000 replications are indicated.

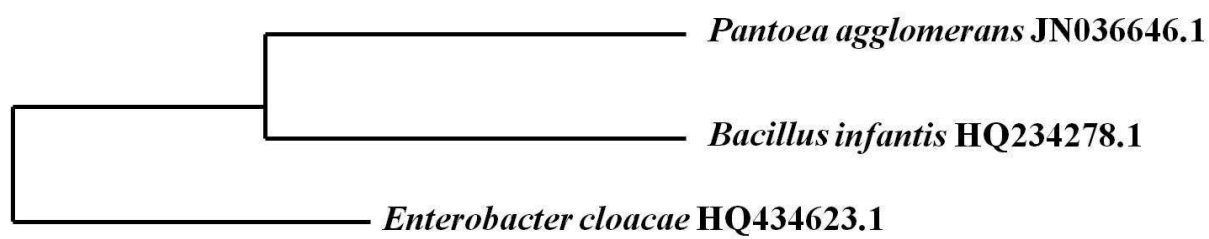

Fig. 2. The phylogenetic tree of the isolated contaminant bacteria found during in vitro culture of potato and tea.

Antibiotic sensitivity of the contaminant bacteria: In previous reports the antibiotic was used to control bacterial contaminant of plant tissue culture (Benjama and Charkaoui 1997, Habiba et al. 2002). Another study demonstrated that the addition of antibiotics e.g. streptomycin, penicillin $G$, tetracycline at 10 
$\mu \mathrm{g} / \mathrm{ml}$ in the micropropagation media was found to be effective in controlling the growth of the bacterial contaminants in tissue culture (Hennerty et al. 1998). Addition of antibiotic dosages in tissue culture may be beneficial where synergistic action occurs. Therefore, culture and sensitivity test was carried out in the present study (Table 4 and Fig. 3).

Table 4. Culture and sensitivity test of the selected bacterial isolates.

\begin{tabular}{lccccccc}
\hline \multirow{2}{*}{ Isolates } & \multicolumn{7}{c}{ Antibiotics and inhibition zone diameter (mm) } \\
\cline { 2 - 8 } & VA-30 & RD-5 & N-30 & S-10 & CN-120 & PB-300 & P-10 \\
\hline Bacillus infantis (Pot-1) & 8.5 & 11.5 & 8.0 & 8.0 & 11.0 & 5.0 & 17.0 \\
B. alcalophilus (Pot-2) & 7.0 & 5.0 & 6.0 & 5.0 & 13.0 & 3.5 & 19.0 \\
Enterobacter cloacae sub. & $\mathrm{R}$ & 2.0 & 5.0 & 8.5 & 11.0 & 4.0 & $\mathrm{R}$ \\
sp. dissolvens (Pot-3) & $\mathrm{R}$ & 2.5 & 5.0 & 3.0 & 7.0 & 4.0 & $\mathrm{R}$ \\
Pantoea agglomerans (T-1) & $\mathrm{R}$ & $\mathrm{n}$ & \\
Bacillus lentus (T-2) & $\mathrm{R}$ & 2.0 & 4.0 & 3.5 & 6.0 & 4.0 & $\mathrm{R}$ \\
B. schlegelii (T-3) & $\mathrm{R}$ & 2.5 & 5.0 & 3.5 & 7.5 & 5.0 & $\mathrm{R}$ \\
B. circulans (T-4) & $\mathrm{R}$ & 3.0 & 5.0 & 3.5 & 7.5 & 4.5 & $\mathrm{R}$ \\
B. pumilus (T-5) & $\mathrm{R}$ & 2.5 & 4.0 & 2.5 & 6.5 & 4.0 & $\mathrm{R}$ \\
B. subtilis (T-6) & $\mathrm{R}$ & $\mathrm{R}$ & $\mathrm{R}$ & 4.0 & 7.0 & 4.0 & 2.0 \\
\hline
\end{tabular}

Disc size $=6 \mathrm{~mm}, \mathrm{R}=$ Resistance.
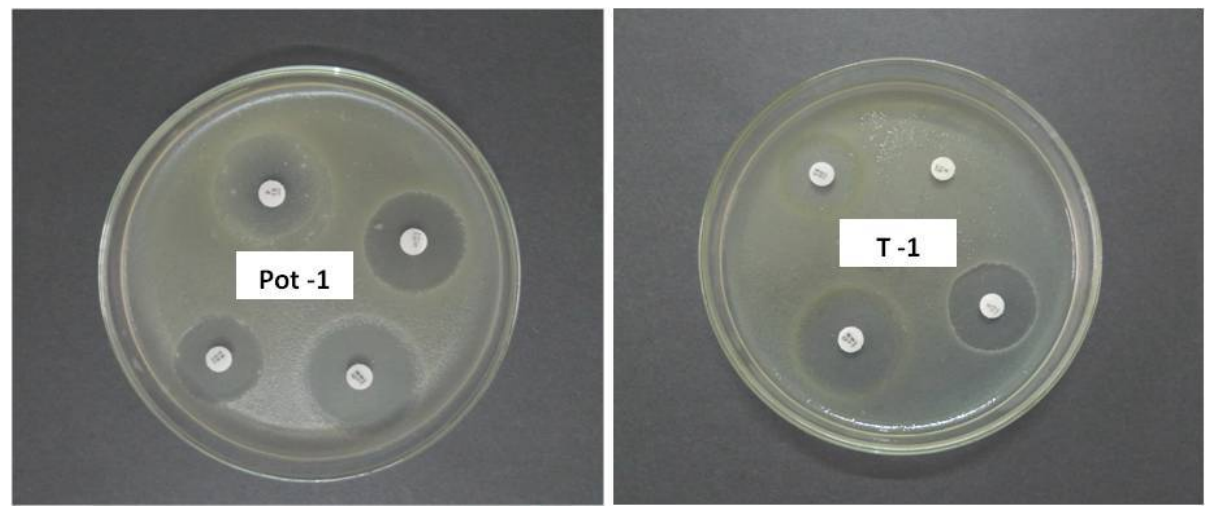

Fig. 3. Culture and sensitivity test using antibiotic discs of the selected isolates.

In another study it was reported that the growth and control of Gram negative bacteria were found to be difficult or unsuccessful by using antibiotics (De et al. 2013). In the present study, the Gram negative bacteria were sensitive to different antibiotics which are good indication to control the contaminants of Gram negative bacteria during in vitro culture of plant. Thus, the culture and sensitivity test might help to find out the possible way to control these organisms in tissue culture. 
All of the bacterial isolates were found to be susceptible to streptomycin (S-10), polymyxin (PB-300) and gentamicin (CN-120), respectively (Table 4 and Fig. 3), which was in agreement to the previous report (Reed et al. 1995). Neomycin (N-30) and rifampicin (RD-5) had shown antibacterial activities against all bacteria except $B$. subtilis. Among seven antibiotics tested penicillin (P10) and vancomycin (VA-30) were found to be less effective against the plant tissue culture contaminants. On the other hand, B. subtilis showed resistance against three antibiotics, namely vancomycin (VA-30), rifampicin (RD-5) and neomycin (N-30). Among nine bacteria, Bacillus infantis and B. alcalophilus were found to be susceptible to all of the antibiotics tested in this study indicated that these two bacterial contaminants may be controlled easily. The result clearly suggested that streptomycin, polymyxin and gentamicin could be used to avoid bacterial contamination during in vitro culture of plants. Falkiner (1990) mentioned that amphicilin and gentamicin inhibit bacterial growth through resisting the cell wall synthesis of bacteria. Hence, it can be assumed that the antibiotic discs used in this study might have controlled the growth of bacteria through preventing their cell wall development. Uses of specific drugs could play an important role in controlling contaminant bacteria in tissue culture which eventually could lead to increase the culture quality and instigate the growth of tissue culture. Through applying antibiotics, the explants mortality rate also could be reduced in tissue culture which could save money, time and reduce hardship of plant biologists.

Both Gram positive and Gram negative bacteria were found to be associated with the tissue culture contaminants. All of the contaminants were found to be sensitive against steptomycin, polymyxin and gentamicin and they were suggested as effective antibiotics to control contaminant bacteria during in vitro culture of potato and tea plants. Moreover, further study could help to find out the specific rate of antibiotic dose for complete suppression of the contaminant bacteria from in vitro culture of experimented plants.

\section{References}

Benjama AH and Charkaoui B (1997) Control of Bacillus contaminating date palm tissue in micropropagation using antibiotics. In: Pathogen and Microbial Contamination Management in Micropropagation. Springer, Dordrecht. pp. 207-211.

Camire ME, Kubow S and Donnelly DJ (2009) Potatoes and human health. Crit Rev Food Sci. Nutr. 49(10): 823-840.

Claus GW (1995) Understanding Microbes (4th ed.). W.H. Freeman and Company, New York. pp. 547. 
Collins CH and Lyne PM (1984) Microbiological Methods (5th ed.) Butterworths Co. (Publishers). Ltd., London. pp. 56-113.

Daniel RL (1998) The many dimension of plant tissue culture research. Webmaster of Aggie Horticulture Publications, pp. 201-210.

De, Nardo P, Giancola M, Noto S, Gentilotti E, Ghirga P, Tommasi C, Bellagamba R, Paglia M, Nicastri E, Antinori A and Corpolongo A (2013) Left thigh phlegmon caused by Nocardia farcinica identified by 16S rRNA sequencing in a patient with leprosy: A case report. Bio Medical Central. 13(1): 162.

Evers D, Lefevre I, Legay S, Lamoureux D, Hausman JF, Rosales ROG, Marca LRT, Hoffmann L, Bonierbale M and Schafleitner R (2010). Identification of droughtresponsive compounds in potato through a combined transcriptomic and targeted metabolite approach. J. Exp. Bot. 61(9): 2327-2343.

Falkiner FR (1990) The criteria for choosing an antibiotic for control of bacteria in plant tissue culture. Newsletter, International Association for Plant Tissue Culture 60: 13-23.

George EF (1993) Plant propagation by tissue culture. Exergetics Ltd. Edington, England. pp. 574 .

Habiba U, Reza S, Saha ML, Khan MR and Hadiuzzaman S (2002) Endogenous bacterial contamination during in vitro culture of table banana: Identification and prevention. Plant Tissue Cult. 12(2): 117-124.

Hennerty MJ (1998) Improving flavour in protected strawberry crops. Farm and Food. 8: 2-21.

Jang-Jih L, Cherng-Lih P, Shih-Yi L and Chih-Chieng W (2000) Use of PCR with universal primers and restriction endonuclease digestions for detection and identification of common bacterial pathogens in cerebrospinal fluid. J. Clin. Microbiol. 38(6): 2076-2080.

Kane M (2003) Bacterial and Fungal Indexing of Tissue Cultures http://www.hos. ufl.edu/mooreweb/TissueCulture/class1/Bacterial\%20and\%20fungal\%20indexing\%20 of $\% 20$ tissue $\% 20$ cultures.doc.

Kolomiets TM, Malyarovskaya VI, Gvasalia MV, Samarina LS and Sokolov RN (2014) Micropropagation of subtropical fruit, ornamental crops and endemics of Western Caucasus: Original and optimized protocols. Agric. Biol. 3: 49-58.

Krieg NR and Holt JG (eds.) (1984) Bergey's Manual of Systematic Bacteriology, Williams and Wilkins, Balrimore, USA. 1: 964.

Lee MS, Hwang YS, Lee J and Choung MG (2014) The characterization of caffeine and nine individual catechins in the leaves of green tea (Camellia sinensis L.) by nearinfrared reflectance spectroscopy. Food Chem. 158: 351-357.

Leifert C and Cassells AC (2001) Microbial hazards in plant tissue and cell cultures. In Vitro Cell Dev. Biol. Plant. 37(2): 133-138.

Marchesi JR, Sato T, Weightman AJ, Martin TA, Fry JC, Hiom SJ and Wade WG (1998) Design and evaluation of useful bacterium-specific PCR primers that amplify genes coding for bacterial 16S rRNA. J. Appl. Environ. Microbiol. 64(2): 795-799. 
Mondal TK, Bhattacharya A, Laxmikumaran M and Ahuja PS (2004) Recent advances of tea (Camellia sinensis) biotechnology, Plant Cell, Tiss. Org. Cult. 76: 195-254.

Odutayo OI, Amusa NA, Okutade OO and Ogunsanwo YR (2007) Detennination of the Sources of Microbial Contaminants of Cultured Plant Tissues. Plant Pathol. J. 6(1): 77-81.

Reed BM, Buckley PM and DeWilde TN (1995) Detection and eradication of endophytic bacteria from micropropagated mint plants. In Vitro Cell Dev. Biol. Plant. 31(1): 53-57.

Sharma A and Agrawal V (2012) Tissue culture aspects of ornamental plants (Review) CIBTech. J. Biotechnol. 1(1): 40-48.

Sneath PHA, Mair NS, Sharpe ME and Holt JG (1986) Bergey's Manual of Systematic Bacteriology, Williams and Wilkins Company, Baltimore, USA. 2: 1120-1329.

Tamura K, Stecher G, Peterson D, Filipski A and Kumar S (2013) MEGA 6: molecular evolutionary genetics analysis version 6.0. Mol. Biol. Evol. 30(12): 2725-2729.

WHO (World Health Organization) (1987) Manual for laboratory investigations of acute enteric infections. CDD/83.3. World Health Organization, Geneva, Switzerland. pp. $1-112$. 